\title{
APPLICABILITY OF THE SECI MODEL OF KNOWLEDGE CREATION IN RUSSIAN CULTURAL CONTEXT: THEORETICAL ANALYSIS
}

\author{
Authors: \\ Tatiana Andreeva \\ Graduate School of Management, St.Petersburg State University, St.Petersburg, Russia \\ Irina Ikhilchik \\ Graduate School of Management, St.Petersburg State University, St.Petersburg, Russia
}

\begin{abstract}
:
While the potential influence of national culture on the efficiency of knowledge management interventions has been widely accepted there is a little discussion concerning the underlying question - are the theories and models of knowledge related processes we use are influenced by culture? SECI model proposed by Nonaka and Takeuchi is very influential in knowledge management community, and its authors repeatedly claim of its universal validity. However, few recent writings challenge this opinion. The aim of this study is to continue this discussion and to explore the limits of applicability of the SECI model in Russian cultural context.
\end{abstract}

Key words: knowledge creation, SECI model, culture, Russia

\section{Corresponding author:}

Tatiana E.Andreeva, Ph.D.

Senior Lecturer,

Organizational Behaviour and Human Resources Management department, Graduate School of Management,

St.Petersburg State University

16, Dekabristov per., St.Petersburg, Russia, 199155

Phone: (7-812) 350-8155 Fax: (7-812) 350-0406

e-mail: andreeva@som.pu.ru 


\section{INTRODUCTION}

Contemporary management theorists and practitioners both view knowledge as one of the key sources for creation and maintenance of sustainable competitive advantage in post-industrial economy (e.g., Grant, 1996). Thus the issues of managing knowledge in organizations are widely discussed and the literature is abundant with different models and best practices that are supposed to increase the efficiency of various knowledge-related processes in organizations.

The process of knowledge creation lies in the very centre of these discussions, because new knowledge is believed to allow a company to leave the competitors behind by undertaking innovative actions (Schumpeter, 1934). Nonaka and Takeuchi proposed to conceptualize the process of knowledge creation in organizational settings by the SECI model that represents the four modes of knowledge creation (socialization, externalization, combination and internalization) (Nonaka, Takeuchi, 1995). This model became very influential and it seems to have been accepted by the most part of the knowledge management community as universally valid in conception and in application (Von Krogh et al., 2000).

The implicit assumptions about cultural universality of the management theories, held both by the authors of these theories and those who read them and apply in their research and practice, have been seriously criticized during the last decades (e.g., Hofstede, 1980; Boyacigiller, Adler, 1991). However, these claims have reached the knowledge management discourse only very recently. While the potential influence of culture (both national and organizational) on the efficiency of knowledge management interventions has been widely accepted (e.g., Bhagat et al., 2002; Chuan, 2005; Alavi et al., 2006) there is a little discussion concerning the underlying question - are the theories and models of knowledge related processes we use influenced by culture? Nonaka and Takeuchi (1995) repeatedly claim of the universal validity of the SECI model. However, few recent writings challenge its universal applicability (Glisby, Holden, 2003; Weir, Hutchings, 2005).

The aim of this study is to continue this discussion and to explore the limits of applicability of the SECI model in Russian cultural context. We start with the overview of the literature on cultural issues in knowledge management, followed by the analysis of SECI model criticisms from cross-cultural perspective. Based on this, we identify the key conditions and management tools that are aimed to support each mode of SECI model. Further on, we focus on Russian cultural profile and develop a set of analytically grounded propositions concerning availability of these conditions and applicability of these tools in Russian cultural context. We conclude with some implications for both knowledge management theory and practice.

\section{NATIONAL CULTURE AND KNOWLEDGE MANAGEMENT: LITERATURE ANALYSIS}

The interrelationship between culture and knowledge management has been recently recognized, both on the level of national (e.g., Bhagat et al., 2002; Javidan et al., 2005; Kohlbacher, Krähe, 2007; Ang, Massingham, 2007) and organizational (e.g., DeLong, Fahey, 2000; Kayworth, Leidner, 2004; Alavi et al., 2006) cultures. Moreover, the need to integrate multiple layers of culture into knowledge management models has been clearly spelled (King, 2007). However, for the sake of brevity, in this particular 
paper we will focus on the level of the national culture. For the purposes of this paper, we define culture as a set of basic shared practices and values that help human communities find solutions to problems of external adaptation (how to survive) and internal integration (how to stay together) (Schein, 1992).

While the number of sources on culture-related issues in knowledge management is growing, the main stream of such literature is dedicated to cross-cultural problems in knowledge sharing/transfer. Though these issues are undoubtedly topical, such a focus, to our mind, has a number of limitations. First, it typically treats culture as a "problem" (a "barrier" as some authors put it (e.g., DeLong, Fahey, 2000; McDermott, O'Dell, 2001)) - differences in culture are typically presented as impediments to knowledge flows. The key shortcoming of such approach is that it prevents organizations from appreciating culture as powerful organizational resource that can be used to contribute to organizational success (Holden, 2002).

Second, knowledge creation has received much less attention from cross-cultural perspective than the knowledge sharing process. Some research has been done on the influence of national culture on innovative activities (Shane, 1992, 1993; Couto, Vieira, 2004). Though knowledge creation and innovation are not fully identical concepts (for discussion, see Andreeva, 2009a), the conclusions of such research can be extended to knowledge creation issues. These authors conclude that cultures with particular characteristics (for example, with high uncertainty avoidance) are less successful in innovative activities. If we accept anthropological view of culture as of a relatively stable phenomenon, such conclusion implies that some countries have "innate" disadvantage in knowledge creation and will be (always) lagging in innovations. We think it is too unrealistic as an argument. Moreover, the SECI model itself (being developed by Japanese authors) and innovative success of Japanese companies, challenge this "stigma" of high uncertanty avoidance, as Japan belongs to this particular cluster of countries. Thus more research on knowledge creation in the light of national cultures is needed to provide us with better understanding of the phenomena.

Third, and probably more important, the most of the culture-related knowledge management literature leaves aside the fundamental question of whether the models used to describe knowledge-related processes are culturally biased. In fact, the dominating approach seeks to include culture in the discussed models as one of the factors of influence, and does not question the culture of the model itself. Being overfocused on culture-in-the-model approach, rather than on culture-of-the-model one, the discipline of knowledge management has been developing predominantly on the basis of the culture-free assumptions despite the fact that management theorists have been already warned of the risks of being culturaly blind (Boyacigiller, Adler, 1991; Hofstede, 1996) at the times when knowledge management discourse was just starting its way to popularity and wide acceptance. To put the argument even stronger, knowledge management has been labelled as the "most universal management concept in history" (Takeuchi, 2001, p.328). Only few voices have been recently raised to question generality and applicability of the models themselves (Glisby, Holden, 2003; Zhu, 2004).

This paper aims to address these conceptual gaps by focusing on the knowledge creation theory and raising the question of its cultural roots and limits of applicability (applying culture-of-the-model approach). In particular, we aim to extend the works of Glisby and Holden (2003) and Weir and Hutchings (2005) by analysing the applicability of the SECI model in Russian cultural context. 


\section{SECI MODEL AND ITS CROSS-CULTURAL APPLICABILITY}

To discuss cultural embeddedness of the knowledge management discourse, we chose to focus on the SECI model of knowledge creation proposed by Nonaka (Nonaka, 1991) as it represents one of the most influential and widely cited models in the field (Von Krogh et al., 2000). Developing the distinction between tacit and explicit knowledge, Nonaka suggested that the creation of new knowledge in organizations can be described with a four-stage spiral model. He abbreviated the model as SECI for the four knowledge conversion modes it includes - socialization, externalization, combination and internalization. The spiral starts with a socialization phase, in which tacit knowledge of individuals is exchanged. This is followed by an externalization phase, in which new tacit knowledge is translated into explicit knowledge. This explicit knowledge is pooled with existing explicit knowledge in the next, combination, phase; and the turn of the spiral concludes with an internalization phase, in which this new explicit knowledge is absorbed by individuals and enriches their tacit knowledge base. Then the tacit knowledge is exchanged again, and the knowledge creation process continues along the spiral.

The model involves two assumptions that are vital for our further analysis. First, Nonaka postulates that knowledge creation is a social process, meaning that knowledge is always created in interaction between people and a single isolated individual has a very limited capability to create new knowledge. Second, Nonaka stresses that an organization can be efficient in knowledge creation reached only if all four knowledge conversion modes are well-performed (we will return to this particular point later).

The vision of knowledge creation as a social/interactive process creates an immediate link to the notion of culture as any social interaction is to some extent defined by culturally-rooted rules and rituals (Schein, 1992). In this light it is surprising that the SECI model was promoted by its authors as a culturally universal concept (e.g. Takeuchi, 2001). The model has been internationally accepted both in the academic and practitioners' world, usually without questioning the cultural limits of its applicability, and only few (though, strong) doubts on whether the model can be equally efficient in different cultural contexts have been voiced recently (Glisby, Holden, 2003; Weir, Hutchings, 2005). Let us see what are the reasons of such doubts.

The first stage of the model, socialization, implies sharing tacit knowledge, both internally and externally. Nonaka and Takeuchi stress that employees must be simply willing to share knowledge to make socialization happen effectively (Nonaka, Takeuchi, 1995). Glisby and Holden (2003) suggest that internal sharing of tacit knowledge is enabled by strong personal affiliation with and commitment to organization, cooperative attitudes between employees (rather than competitive ones) and focus on developing close relationships with those who share the same fate (work for the same organizations). However, all of these features are usually claimed to be distinctively Japanese. As for external sharing of tacit knowledge, Glisby and Holden claim that it is facilitated by the existance of the networks of partners and close interrelationships between companies in the industry that characterize Japanese cultural context but may not be present in other societies. Thus Glisby and Holden argue that the socialization mode of knowledge conversion is itself a deeply Japanese process.

In contrast, Weir and Hutchings (2005) in their analysis of the applicability of the SECI model in Chinese and Arab contexts suggest that networking is a traditional 
and wide-spread practice both in China and Arab world and thus conclude that socialization works quite effectively in these contexts. However, Weir and Hutchings also mention that Chinese networks are mostly "short-distance" ones, meaning that in organizational settings they are mostly concentrated inside departments, rather than between departments, not to say between organizations. In our view, this fact implies, contrary to the conclusion of the authors, that at least external sharing of tacit knowledge is limited in Chinese cultural context as compared to Japanese one.

The next stage of the SECI model, externalization, implies converting tacit knowledge into explicit one. Nonaka and Takeuchi stress that this stage of the model is the most difficult and time-consuming one, and emphasize the importance of group commitment for its realization. However, many sources suggest that group orientation is a specific feature of the Japanese culture (e.g., Hofstede, 2001). In addition to this, Glisby and Holden (2003) suggest that Japanese organizations experience much less pressure from shareholders than their Western counterparts, and thus they simply can spend their resources (including time) more freely to do things the way they want to do, which includes externalizing knowledge. Weir and Hutchings (2005) report that Chinese organizations run externalization almost the same way as Japanese companies do. However, they claim that in the Arab culture externalization works not exactly the way it is supposed to according to the SECI model.

The third stage of the SECI model, combination, is also claimed to be supported by some typically Japanese practices, such as lack of interdepartmental rivalry, polychronic task orientation, consultative decision-making, purposeful overlap of functional responsibilities ("organizational redundancy" (Nonaka, Takeuchi, 1995)), and more secure context for free and open access to organizational information due to high personal commitment and relatively permanent occupation (Glisby, Holden, 2003). All these factors are supposed to stimulate combination of explicit knowledge across organization, both vertically and horizontally.

Both China and Arab world, according to Weir and Hutchings (2005), are characterized by much more concentrated authority and decision-making in comparison to Japan. Yet they suggest that the strong family spirit prevailing in Arab business still lets opinions of "younger" members to be taken into account, while China does not have mechanisms to compensate for such management style. Weir and Hutchings conclude that combination still happens efficiently in Arab context and does not work well in Chinese one. Further on, they argue that this observation concurs with the idea that efficient combination of knowledge has powerful roots in distinctive Japanese features and management practices and may not be applied universally. To our mind this conclusion is controversial. We suggest that observations of Weir and Hutchings, on the contrary, prove the limited applicability of combination in non-Japanese context.

The last stage of SECI, internalization, involves converting explicit knowledge into tacit through direct experience. Nonaka and Takeuchi stress the importance of the practice of rotation to support it (Nonaka, Takeuchi, 1995). Glisby and Holden (2003) suggest that, plus to intensve rotation, such typicall Japanese practices as the focus on developing generalists rather than specialists in one narrow domain, and wide acceptance of learning-by-doing (or experimental learning) all together create a context for efficient internalization.

Weir and Hutchings (2005) report that in the Arab context rotation is considered to be a good tool, but it is not widely spread. Moreover, it is typically not aimed to 
change the employee's competences significantly, so the focus is still on specialists. In China rotation is quite a new and unfamiliar technique, that is not widely used as people do not like crossing boundaries in their work. Plus to this, Weir and Hutchings suggest that Chinese cultural context features strong fear of mistakes, that inhibits both rotation and learning-by-doing. Thus they agree with Glisby and Holden (2003) that the depiction of internalization proposed in the SECI model does not have universal application.

To summarize, Glisby and Holden (2003) claim that each of the four modes of SECI model are deeply Japanese rooted, and Weir and Hutchings (2005), on the contrary, argue that their study proves that SECI model can be applied in non-Japanese context. Agreeing with Glisby and Holden suggests that SECI model should be treated only as a strongly culturally biased metaphor that has no implications outside of the Japanese reality. Though the arguments of Glisby and Holden are very convincing, we feel that this is too strong as a statement. Otherwise, how can one explain the enourmous popularity of SECI model around the globe? If so many practitioners and academics from different cultures find Nonaka and Takeuchi book inspiring, does not it mean that the model recalls something familiar to them, at least partially?

While we understand the logic of Glisby and Holden, we find the account of Weir and Hutchings (2005) to be highly controversial. Careful investigation of the their arguments suggests that they either illustrate how Arab/Chinese contexts are similar to Japanese one and thus allow some SECI modes to function properly, or provide vivid examples that SECI modes do not work if the context is too different from Japanese one. Based on the observation that some of SECI modes do have application in nonJapanese contexts, Weir and Hutchings infer that the whole model is applicable elsewhere. However, it contradicts the basic idea of Nonaka and Takeuchi, according to whom all modes need to function well in order to result in efficient knowledge creation in an organization. Thus we suggest that Weir and Hutchings conclusion that SECI model is more applicable than Glisby and Holden suggest, is questionable, and that their own account demonstrates that SECI works only in the contexts that are very close to the context where it originated.

Thus we see that the very limited sources on the cultural roots and cross-cultural applicability of SECI model create a contradictory picture. We suggest that one of the reasons for such situation is that these sources treat different elements/levels of the SECI model all together, while distinguishing them and analysing separately may provide a more clear solution. We address this in the next paragraph.

\section{SECI DECOMPOSITION}

Despite its controversies, Weir and Hutchings (2005) article provides some very interesting facts. Consider their account of combination mode in Arab context: they suggest that combination works well there despite highly concentrated authority and decision-making, because familial approach compensates their deficiencies. We see a very interesting situation: combination as a process and a stage of the SECI model can work in the non-Japanese cultural context, but the tools used to support it are different from those that are usually implemented in Japan. This leads us to the idea that in order to discuss cross-cultural applicability of SECI model one needs to distinguish between basic processes of SECI and conditions and tools that enable them. 
We suggest that for the sake of the valid cross-cultural analysis it is useful to distinguish between the following elements of the SECI model: (1) cognitive processes (conversion of tacit and explicit knowledge), (2) societal and organizational conditions and (3) management tools that, according to Nonaka and Takeuchi, facilitate the above mentioned cognitive processes and channel them according to organizational objectives. We propose to distinguish between conditions and tools based on the level of their liability to managerial intervention. While application of tools depends mainly on the free will and decision of the particular manager, the conditions evolve as a result of influence of multiple factors, with managerial actions being just one among them (and sometimes minor one). For example, rotation as organizational practice falls into "tools" category, and high commitment of employees to organization refers rather to "conditions". Of course, this distinction is to some extent voluntaristic - in the example above, on the one hand, introduction and efficiency of rotation depends not only on managerial decisions but also on environmental and cultural factors, and on the other hand, employees' commitment can be increased or ruined by actions of a manager. However, we believe that such separation is useful for the purposes of our analysis.

We proffer that basic cognitive processes of knowledge conversion transformations betweet tacit and explicit knowledge - are natural to mental activities of any human being. We accept that depending on its cultural background, human mind may feel more comfortable with some of these processes as compared to other. For example, consider the influence of the high/low context of culture (Hall, 1959) on the preferences for cognitive processes. In the US companies (low context culture) both managers and employees prefer organizational culture to be explained through images and presentations, whereas in most Russian companies (high context culture) organizational culture is just "absorbed" by employees during their work without additional formalized and explicit explanations. Moreover, many Russian employees perceive explicit explanations of organizational culture as artificial and irritating. Nonaka and Takeuchi (1995) themselves cite similar example, suggesting that Japanese feel more comfortable about tacit knowledge, while Westerners prefer to deal with explicit one. However, all of them, Russians and Americans, Japanese and Westerners, deal with both types of knowledge, and thus we argue that all of four basic cognitive processes in SECI model happen to human beings irrespectively of their culture.

Some authors argue that these cognitive processes may evolve simultaneously or in the order, different to the one suggested in SECI model (Gourlay, 2003; Zhu, 2004). We agree with this point, however, we believe that the order of the cognitive processes does not matter much for cross-cultural analysis from the practical/managerial point of view, as supporting conditions exist, and the tools need to be applied, simultaneously. That is why in our further analysis we leave the debate on the sequence of the cognitive processes, just accepting that they exist.

Having adopted this 3-level framework, we read carefully once more again though both Nonaka and Takeuchi ideas, as well as through Glisby and Holden analysis, in order to identify and segregate the conditions and tools involved into SECI model. Results of our analysis are presented in the Table 1. 
Table 1: Conditions and Tools for SECI Stages (Japanese cultural context)

\begin{tabular}{|c|c|c|}
\hline Stage of SECI & $\begin{array}{c}\text { Societal/organizational } \\
\text { conditions }\end{array}$ & Managerial tools \\
\hline Socialization & $\begin{array}{ll}\text { - Individuals are } \\
\text { willing to share } \\
\text { knowledge, both } \\
\text { internally and } \\
\text { externally } \\
\text { - } \\
\text { High employees' } \\
\text { commitment/loyalty } \\
\text { - Cooperation between } \\
\text { employees (rather } \\
\text { than competition) } \\
\text { Organizations are } \\
\text { parts of wide } \\
\text { networks of partners }\end{array}$ & $\begin{array}{l}\text { - Job design allows sharing } \\
\text { experience, observation, } \\
\text { imitation } \\
\text { - Mentoring }\end{array}$ \\
\hline Externalization & $\begin{array}{ll}- & \text { High group } \\
\text { commitment } \\
\text { - } \quad \text { Little external control } \\
\text { (little pressure from } \\
\text { shareholders) }\end{array}$ & $\begin{array}{l}\text { Wide usage of metaphors, } \\
\text { analogies and models in } \\
\text { explanations } \\
\text { Open dialogue of employees } \\
\text { with each other and } \\
\text { managers } \\
\text { - Communities of practice }\end{array}$ \\
\hline Combination & $\begin{array}{l}\text { - } \begin{array}{l}\text { No inter- } \\
\text { departmental rivalry }\end{array} \\
\text { - High employees' } \\
\text { commitment/loyalty } \\
\text { (no risk of } \\
\text { informational abuse) } \\
\text { - Polychronic/syncrono } \\
\text { us orientation }\end{array}$ & $\begin{array}{ll}\text { - } & \begin{array}{l}\text { Purposeful overlap of } \\
\text { functional responsibilities } \\
\text { (redundancy) }\end{array} \\
\text { - } & \text { Free access to corporate } \\
\text { information (as a policy and } \\
\text { via usage of information } \\
\text { technologies and data bases } \\
\text { - Consultative decision- } \\
\text { making }\end{array}$ \\
\hline Internalization & - $\quad$ Little fear of mistakes & $\begin{array}{ll}\text { - } & \text { Policies that allow } \\
\text { intensive/frequent learning- } \\
\text { by-doing } \\
\text { - } \\
\text { - } \\
\text { - } \text { Gotation between functions } \\
\end{array}$ \\
\hline
\end{tabular}

While Glisby and Holden (2003) claim that some modes of SECI model are totally Japanese-specific, we suggest a more fine-grained approach using our 3-level framework. We propose that on the level of the cognitive processes the model is culturally universal, as it refers to the basic mental processes valid for any human being. We argue, however, that organizational and societal conditions and managerial tools that enable and support these cognitive processes, can be culturally contingent. Further on we will explore if conditions and tools involved in Nonaka and Takeuchi model can be applied in Russian cultural context. 


\section{CONTEXT \\ 5. SECI CONDITIONS AND TOOLS IN RUSSIAN CULTURAL}

We suggest that Russia provides an interesting field for the analysis of crosscultural applicability of SECI elements. First, Nonaka and Takeuchi (1995), as well as Glisby and Holden (2003) stress the Western - Eastern divide in the conceptual tradition and management discourse, while Russia represents another "world" that falls out (or in the middle) of this dichotomy. Second, though some research has been done on the applicability of foreign management theories in Russia in general (Elenkov 1998; Fey, Denison 2003; Andreeva, 2008), only a few of them discuss the knowledge management related issues (May et al. 2005). Third, the existing literature on knowledge management issues in Russia focuses predominantly on knowledge sharing issues (Michailova, Husted, 2003; Michailova, Hutchings, 2006) and does not touch directly upon knowledge creation. Finally, Nonaka and Takeuchi's "Knowledgecreating company" book has been translated in Russian and has had tremendous success, both among academics and managers. In fact, it is the key international book on knowledge management, most widely used and discussed in Russia. Thus deeper understanding of the limits of applicability of the SECI model in Russia is important not only from the theoretical perspective, but also will contribute to the development of the more efficient knowledge management practices in Russian companies.

Our analysis rests on existing writings on Russian management and culture and generalized experience of the authors as management researchers and business consultants to Russian companies. We take societal and organizational conditions, inherent in SECI model, and managerial tools aimed to support SECI modes (all summarized in Table 1), and analyse if they exist in Russian cultural context.

Let us first address societal and organizational conditions, inherent in SECI model. While Nonaka and Takeuchi's ideas are heavily based on the assumption that individuals are willing to share knowledge, both internally and externally, this seems not to be the case in Russia (Michailova, Husted, 2003; Michailova, Hutchings, 2006). Ever worse, Michailova and Husted label Russian organizations as inherently hostile to knowledge sharing (Michailova, Husted, 2003). One of the key reasons for this can be deeply hold belief that knowledge is (individual) power and thus should not be shared unless necessary, and unless proper benefits are received.

Another assumption Nonaka and Takeuchi refer to is high employees' commitment to organization. Russian employees typically show medium to low commitment to their organizations (e.g., May et al., 1998). This trend is a result of decades of economic instability and drastic changes both on societal and organizational levels, when mass lay-offs, serious salary payment delays and significant reductions of wages were very common (Gurkov, Zelenova, 2007).

Next assumption inherent to SECI relates to the dominance of cooperation between employees over the competition between them, both on the individual and on interdepartmental level. Though the situation regarding this may differ between various Russian companies, on average, on the interdepartmental level they typically show strong competitive attitudes (e.g., Fey et al., 1999). Inside the units both situations can be seen.

Regarding the intensity of networking with external partners, it differs in Russian among different industries, but usually is not very strong. Competitive 
atmosphese and obsession with privacy of information in many cases prevent Russian companies from building relationships with external partners. In some industries such types of networks existed during the times of planned economy, but most of the links were destroyed after reforms.

Russian companies tend to differ much from their Japanese counterparts in the prevailing attitude to mistakes, as usually the fear to make a mistake dominates. For example, this is one of the reasons for which delegation of responsibilities does not work well in many Russian companies - middle managers frequently prefer not to act at all in order to avoid mistakes (Shekshnia, 1994; Kets De Vries, 2000)).

Describing Russia along collectivism and group orientation does not have an unambigious answer. Though Russia is often believed to have collectivistic mentality, it might be the result of the point of comparison: some research positions Russia in the middle of the individualism - collectivism scale (Ralston et al., 1997; Hofstede, 2001). Thus being more collectivistic than USA, Russia appears to be more individualistic than Japan. Some findings even indicate a trend for increasing individualism in Russia (Veiga et al., 1995). Other researchers report unusual combination of individualistic and collectivistic attitudes (Holt et al., 1994). One of the explanations lies in the distinction between institutional and in-group collectivism (see House et al., 2004): Russians tend to be collectivistic of the level of small groups, while as soon as they exit their "inner circle", they can demonstrate more individualistic behavior.

Yet, there are some societal and organizational conditions that are similar in Russian and Japanese context. Like Japanese firms, most of Russian organizations are subject to moderately low external control: majority of Russian companies have very concentrated ownership, and in those who have big number of shareholders the latter have very limited possibilities to exert the pressure. And the last issue concerns polychronic time orientation, which also characterizes Russia.

Now let us turn to managerial tools that are meant to support SECI, and see if they have a potential for wide application in Russian companies. Mentoring has been a common practice during Soviet times, and still used nowadays, but usually in much more limited sense compared to what Nonaka and Takeuchi suggest. Most companies limit mentoring to probation period of new employee, and mentor's responsibilities concern mainly explaining general organizational policies rather than intensive sharing experience and teaching through observation and limitation. While some managers recognize the potential of the "deeper" mentoring, they typically face a problem of involving mentors into such process, due to time pressure potential mentors have to complete their routine tasks, as well as to competitive environment in organizations. Moreover, drastic economic changes with mass lay-offs made senior employees (potential mentors) reluctant to share their knowledge and experience due to the fear of being dismissed and replaced by younger employees (e.g., Andreeva, 2009 b).

Our first idea was to link the usage of metaphors, analogies and models in explanations to the uncertainty avoidance dimension of culture (Hofstede, 2001; House et al., 2004) and to suggest that metaphors would be more accepted in low uncertainty avoidance societies. However, SECI model itself contradicts this idea, as Japan has a very high uncertainty avoidance score (Hofstede, 2001; House et al., 2004), and yet it's namely Japanese Nonaka and Takeuchi, who, drawing upon the experience of Japanese companies, promote wide usage of metaphors. We suggest that this situation represents one of the cultural paradoxes (Osland, Bird, 2000) and provides vivid illustration that 
one needs a more fine-grained approach to analysis of the culture issues in knowledge management than just relying on the scores of some culture dimensions. Other grounds for the level of the acceptance of metaphors in organizational settings can be traced to high/low context of culture (Hall, 1959) and to the language structure. People in high context cultures are used to derive the meaning not only from the direct verbal message, but from the multiple contextual factors as well. Thus the meaning can have multiple interpretations. We believe that metaphors are percieved and interpreted in the similar way; and both Russia and Japan have high context cultures. Moreover, Russian language is characterized by flexible word sequence and very rich in adjectives and adverbs. Thus we suggest that metaphors can be widely used and accepted in Russian organizations.

Consultative decision-making as a part of leadership style is inherent to SECI model. However, many studies suggest that such type of leadership is not widely practiced by Russian managers (Ardichvili et al., 1998; Kets De Vries, 2000) - both due to the historical heritage of the leaders (Shekshnia, 2004) and due to attitudes of the followers (Fey et al., 1999).

The next managerial tool proposed by Nonaka and Takeuchi - open dialogue of employees with each other and managers - also seems to be problematic for the wide application in Russian companies. One of the reasons is tensions between managers and employees that are typical for many Russian organizations (e.g., May et al., 1998). Another reason relates to the attitude to information and knowledge, that we have already mentioned above - it is regared as as power that should be shared without serious reason (Michailova, Husted, 2003). Reinforced with high power distance and rather autoritarian leadership style, all these factors lead to the situation, when top-down communications prevail, and when employees, on the one hand, do not have a lot of opportunities for discussions with senior management, and on the other hand, they are not motivated to take such opportunities when they arise.

All these issues influence potential of application in Russian companies for yet another SECI tool - free access to corporate information (as a policy and via usage of information technologies and data bases). Not only Russian employees are reluctant to share information. Russian companies as well are known for their obsession with secrecy of any kind of information related to their business and reluctance to share it both internally and externally. Thus we suggest that the key barrier to implementation of the free access of employees to internal information in Russian companies lies in the attitudes of Russian managers.

Application of job design that allows sharing experience, observation and imitation, also does not seem to be very easy in Russian companies, as it needs a little fear of mistakes (that is not the case in many Russian companies as we ave already mentioned) as well as enough time for experimentation, that can be difficult to negotiate with managers due to the dominating focus on the short-term results (Fey et al., 1999). The same reasoning applies to another SECI-supporting tool, policies that allow intensive learning-by-doing.

Employees' rotation between functions can be potentially used in Russian companies, and some big companies have already started using this practice. Yet we suggest that it can face reluctance from the side of the employees, partly due to the fear of mistakes and partly due to the strength of the in-group ties together with competitive relations between departments. 
Nonaka and Takeuchi view communities of practice as a useful tool to support knowledge creation. Taking into account specifics of Russian collectivism, that we described above, we argue communities of practice in Russian will tend to be focused within departments or functions, and special efforts should be made to help them to transgress the limits of small "in-groups".

Application of purposeful overlap of functional responsibilities (redundancy) in Russian companies provides controversial evidence. On the one hand, many Russian companies de facto have such overlap. However, such overlap typically has not been established intentionally, rather it developed naturally with the growth of the company due to the lack of attention of the managers to organizational structuring. Unintentional nature of such redundancy together with highly competitive environment inside the company usually leads to many conflicts both on individual and interdepartmental level. Thus, in order to optimize organizational processes, reduce costs and diminish conflicts, many Russian managers in fact seek to eliminate such redundancy. We see very similar sutiation with the generalistic job descriptions - while many Russian organizations de facto use them, they are usually perceived by employees as a result of mismanagement and potential source of conflicts.

Table 2 presents the summary of our analysis. It demonstrates that, unlike in Glisby and Holden's (2003) Japan-West comparison, there are both differences and similarities between Russian and Japanese contexts, in terms of existance of societal and organizational conditins that support SECI basic cognitive processes, and of applicability of managerial tools that enable them. Yet one can see that the differences heavily outweigh the similarities. Moreover, we suggest that the differences in conditions are more grave than the differences in diffusion of tools, because, as we proposed above, the managers' potential to change conditions is much more limited.

Table 2: Comparison of Russian and Japanese cultural contexts through SECI lenses

\begin{tabular}{|c|c|c|}
\hline SECI elements & Similarities & Differences \\
\hline $\begin{array}{ll}\text { Basic } & \text { cognitive } \\
\text { processes } & \\
\end{array}$ & $\begin{array}{l}\text { - Four knowledge } \\
\text { conversion modes }\end{array}$ & - $\mathrm{n} / \mathrm{a}$ \\
\hline $\begin{array}{l}\text { Societal and } \\
\text { organizational } \\
\text { conditions }\end{array}$ & $\begin{array}{l}\text { - Level of external control } \\
\text { (pressure from } \\
\text { shareholders) } \\
\text { - Polychronic/syncronous } \\
\text { orientation } \\
\text { - Group orientation (?) }\end{array}$ & $\begin{array}{l}\text { - Natural willingness of } \\
\text { individuals to share } \\
\text { knowledge } \\
\text { - Level of employees' } \\
\text { commitment / loyalty } \\
\text { - Cooperative vs. } \\
\text { competitive attitudes } \\
\text { (both in individual and } \\
\text { interdepartmental } \\
\text { level) } \\
\text { - Organizational } \\
\text { involvement in } \\
\text { extensive networs } \\
\text { - Attitude to mistakes }\end{array}$ \\
\hline Managerial tools & $\begin{array}{l}\text { - Usage of metaphors, } \\
\text { analogies and models in } \\
\text { explanations }\end{array}$ & $\begin{array}{l}\text { - Job design allows } \\
\text { sharing experience, } \\
\text { observation, imitation } \\
\end{array}$ \\
\hline
\end{tabular}




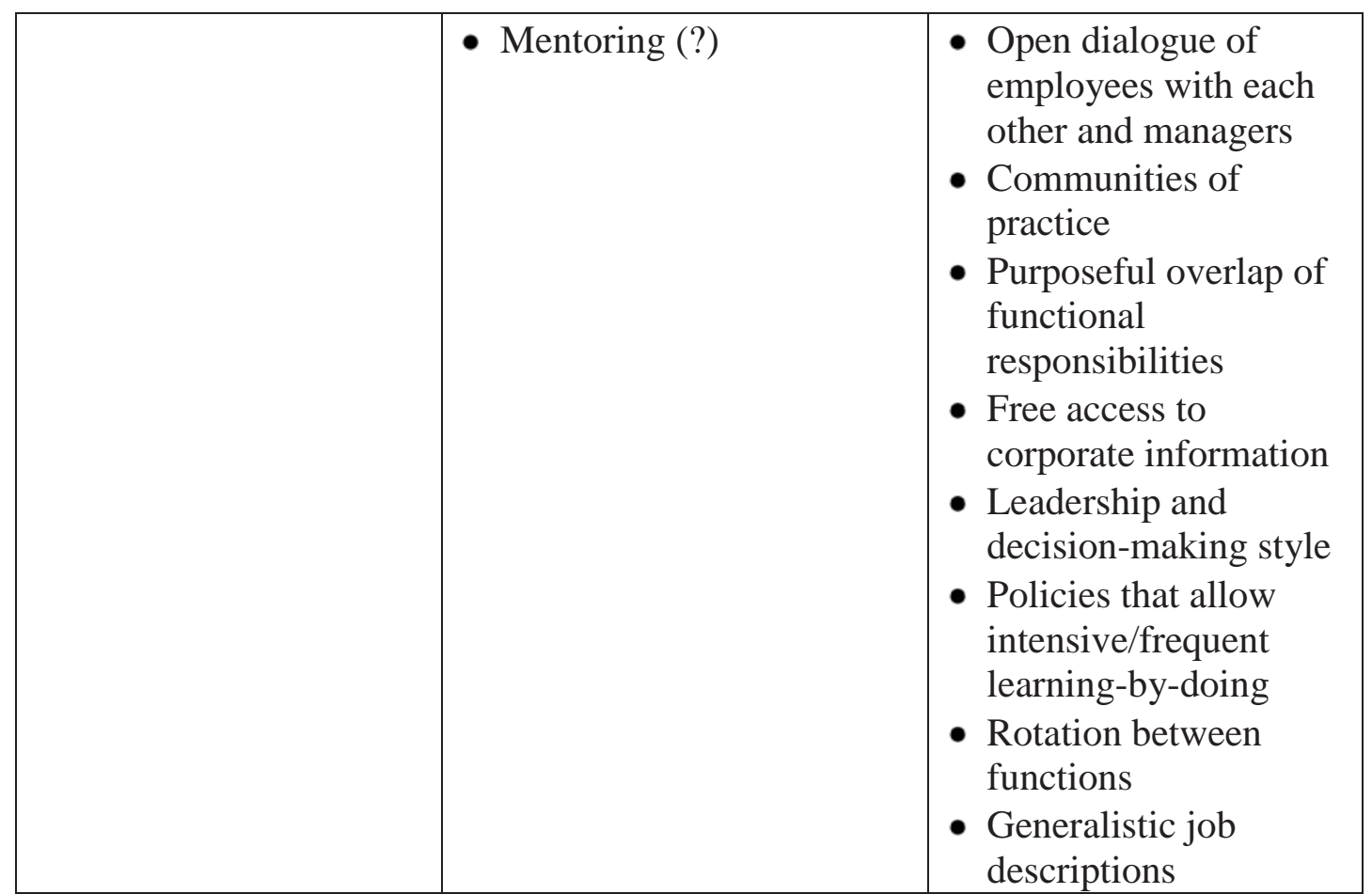

What is the conclusion: can SECI be applied in the Russian cultural context or not? Based on our idea that the cognitive processes themselves are culturally universal, we believe that four knowledge conversion modes of SECI apply in Russian context. However, taken into account specifics of the Russian context, we propose that in order to support smooth functioning of these modes, the set of tools managers need to implement, has to differ from what Nonaka and Takeuchi promote. Such set of actions can be focused both on leveraging the conditions and tools that are similar to Japan, and on compensating the differences. What particular set of actions can fit best Russian companies to support knowledge creation, is an interesting question for further research. Yet, based on our analysis, some ideas and hypotheses can be formulated.

First, it is important to stress that, according to Nonaka and Takeuchi, four conversion modes happen at different levels in the organization (Nonaka and Takeuchi, 1995). While socialization mainly takes place in pairs or small groups, externalization evolves in small groups or inside units, and combination runs between the units, on the level of the whole organization. Thus, taking into account peculiarities of Russian group orientation (high in-group collectivism along with rather individualistic behaviour demonstrated in bigger communities), we suggest that socialization in Russian companies will run more smootly, while more efforts from managers are needed to support combination.

Second, we hypothesize that attitudes towards knowledge as power can be surmounted with the help of the relevant and well-thought remuneration system. Michailova and Husted (2003) suggest that in (Russian) organizations, hostile to knowledge-sharing, negative rewards (punishment) can be very useful. However, we have some doubts whether such approach is always efficient to increase knowledge creation.

Next, we suggest that one more attitude needs to be destroyed - towards knowledge as secret. As far as it is Russian managers who typically share such attitude, probably some efforts on more institutional level can help, for example, through 
management education and literature. Interventions on such level can also help to change the attitudes towards knowledge exchange with external parties.

\section{CONCLUSIONS}

We suggest that our analysis provides several contributions to the contemporary discourse on knowledge management.

First, it extends existing academic discussion of the applicability of the SECI model in various cultural contexts and thus challenges the mainstream assumptions about the universalism of this model. In our view, the deeper apprehension of the cultural roots and limits of applicability of basic knowledge management concepts will enrich both the understanding of the phenomenon of knowledge in organizations), and practical efficiency of knowledge management interventions through the wider repertoire of metaphors (Andriessen, 2007) and tools.

Second, SECI decomposition we developed may serve as a ground for the empirical research on the SECI model that is in serious lack now. It has been noted that SECI model is very difficult for empirical research due to its philosophical nature (Rice and Rice, 2002). We suggest that re-framing SECI model into three levels, as we proposed, opens doors to empirical research as it provides possibilities for operationalization of the variables

Third, the analytical 3-level framework we developed can be used both for analysis of SECI model applicability and for development of practical recommendations how to increase its' efficiency in different cultural contexts. Forth, it suggests how SECI framework should be adapted to a particular (Russian) culture and thus may increase efficiency of knowledge management interventions in Russia.

And the last issue in fact links us not to the knowledge management discourse but rather to the discourse on culture in management sciences. We believe that treating culture from the culture-of-the-model point of view helps to overcome the mentioned above problem of the negative connotations to culture (Holden, 2002). Within such approach culture can be viewed as a filter or lense rather than a barrier.

Linking to the main theme of the OLKC-2009, our analysis is aimed to connect the worlds of knowledge management and cross-cultural management disciplines, as well as the worlds of theory (models) and practice (applicability). 


\section{REFERENCES:}

1. Alavi, M., and Kayworth, T.D., and Leidner D.E. (2006), 'An Empirical Examination of the Influence of Organizational Culture on Knowledge Management Practices, Journal of Management Information Systems, vol. 22 no. 3, pp.191-224.

2. Andreeva T. (2008), Can organizational change be planned and controlled? Evidence from Russian companies', Human Resource Development International, vol. 11 no.2, pp.119-134.

3. Andreeva, T. (2009a), 'Tensions between knowledge creation and knowledge sharing: Individual preferences of employees in knowledge-intensive organizations', Chapter XXVIII in Kociatkiewicz, J., Jemielniak, D. (ed.), Handbook of Research on Knowledge-Intensive Organizations, Hershey-New York: Information Science Reference, pp. 459 - 476.

4. Andreeva, T. (2009b), 'Knowledge exchange as a success factor. An example of the OAO Mekhanobr-Tekhnika Research Corporation', case study, ECCH, registration no. 909-001-1.

5. Andriessen, D. (2007), 'Knowledge as love: how metaphors direct the way we manage knowledge in organizations', Paper for the $5^{\text {th }}$ Critical Management Society conference, 11-13 July 2007, Manchester, UK.

6. Ang, Z., Massingham, P. (2007), 'National culture and the standardization versus adaptation of knowledge management', Journal of Knowledge Management Vol.11, no.2, pp. 5-21.

7. Ardichvili, A., Cardozo, R.N. and Gasparishvili, A. (1998) 'Leadership Styles and Management Practices of Russian Entrepreneurs: Implications for Transferability of Western HRD Interventions', Human Resource Development Quarterly 9(2):145-55.

8. Bhagat, R. S. et al. (2002), 'Cultural Variations in the Cross-Border Transfer of Organizational Knowledge: An Integrative Framework', Academy of Management Review, vol. 27 no. 2, pp.: 204-221.

9. Boyacigiller, N.A. and Adler, N.J. (1991), 'The parochial dinosaur: organizational science in a global context', Academy of Management Review, vol. 16 no.2, pp. :262-90.

10. Chuan L., and Wen-Jung Ch. (2005), 'The Effects of Internal Marketing and Organizational Culture on Knowledge Management in the Information Technology Industry', International Journal of Management vol. 22 no. 4, pp.: 661-672.

11. Couto, J.P., Vieira, J.C. (2004), 'National Culture and Research and Development Activities', Multinational Business Review, vol. 12 no. 1, pp. 19-35.

12. DeLong, D.W., and Fahey, L. (2000), 'Diagnosing cultural barriers to knowledge management', Academy of Management Executive, vol. 14 no., 4, pp. 113127.

13. Elenkov, D.S. (1998), 'Can American management concepts work in Russia? A cross-cultural comparative study', California Management Review, vol. 40 no. 4, pp.:133-56.

14. Fey, C.F. and Denison, D. (2003), 'Organizational culture and effectiveness: Can American theory be applied in Russia?', Organization Science, vol. 14 no. 6, pp. :686-706.

15. Fey, C.F., Nordahl, C. and Zatterstrom, H. (1999) 'Organizational Culture in Russia: The Secret to Success', Business Horizons 42(6): 47.

16. Glisby M., Holden N. (2003), 'Contextual constraints in knowledge management theory: the cultural embeddedness of Nonaka's knowledge-creating company', Knowledge \& Process Management, vol. 10 no.(1), pp. 29-36. 
17. Gourlay, S. (2003), 'The SECI model of knowledge creation: some empirical shortcomings', In: 4th European Conference on Knowledge Management, 1819 Sep 2003, Oxford, England, available at http://myweb.tiscali.co.uk/sngourlay/PDFs/Gourlay\%202004\%20SECI.pdf

18. Grant, R.M. (1996), 'Toward a Knowledge-based Theory of the Firm', Strategic Management Journal, vol. 17 (Winter Special Issue), pp. 109-122.

19. Gurkov I., Zelenova O. (2007), 'Human resource management in Russia’, available

at

http://www.gurkov.ru/publ_html/publik/2006/GURKOV_ZELENOVA-FIN.pdf

20. Hall, E.T. (1959), The Silent Language, New York: Doubleday.

21. Hofstede G. (1980), 'Motivation, Leadership and Organization: Do American Theories Apply Abroad?', Organizational Dynamics, pp. 42-63.

22. Hofstede, G. (1996), 'An American in Paris: The Influence of Nationality on Organization Theories', Organization Studies (Walter de Gruyter GmbH \& Co. KG.), vol.17, no.3, pp.525-537.

23. Hofstede, G. (2001). Culture's Consequences: Comparing Values, Behaviors, Institutions, and Organisations Across Nations, 2nd edition. Thousand Oaks, CA: Sage.

24. Holden, N. (2001), 'Knowledge Management: Raising the Spectre of the Cross-cultural Dimension', Knowledge \& Process Management, vol. 8 no.3, p155-163.

25. Holden, N.J. (2002), Cross-cultural management: a knowledge management perspective. Prentice Hall.

26. Holt, D. H., Ralston, D. A. and Terpstra, R. H. (1994). 'Constraints on capitalism in Russia: the managerial psyche, social infrastructure, and ideology'. California Management Review, 36, 3, 124-41.

27. House J. et al. (2004), Culture, Leadership, and Organizations. The GLOBE Study of 62 Societies. Thousand Oaks: Sage Publications, Inc.

28. Javidan, M., Stahl, G.K., Brodbeck, F., Wilderom, C. (2005), 'Crossborder transfer of knowledge: Cultural lessons from Project GLOBE', Academy of Management Executive, May2005, vol. 19 no.2, pp. 59-76.,

29. Kayworth, T., Leidner, D. (2004), 'Organizational Culture as a Knowledge Resource', Handbook on Knowledge Management 1: Knowledge Matters, 2004, pp. 235-252, 18p.

30. Kets De Vries, M.F.R. (2000) "A Journey into the "Wild East": Leadership Style and Organizational Practices in Russia', Organizational Dynamics 28(4):67-82.

31. King, W. R. (2007), 'A research agenda for the relationships between culture and knowledge management', Knowledge \& Process Management, vol. 14 no.3, pp. 226-236.

32. Kohlbacher, F., Krähe, M. (2007), 'Knowledge creation and transfer in a cross-cultural context - empirical evidence from Tyco Flow Control'. Knowledge \& Process Management, vol. 14 no.3, pp. 169-181.

33. May, R., Young, C. B., Ledgerwood, D. (1998), 'Lessons from Russian human resource management experience', European Management Journal, Vol. 16, no.4, pp.:447-459.

34. May, R.C., Puffer, S.M. and McCarthy, D.J. (2005), 'Transferring management knowledge to Russia: A culturally based approach', Academy of Management Executive vol. 19, no.2, pp. 24-35.

35. McDermott, R., and O'Dell, C. (2001), 'Overcoming culture barriers to sharing knowledge', Journal of Knowledge Management, vol. 5 no.1, pp.76-85.

36. Michailova, S., Husted, K. (2003), 'Knowledge-Sharing Hostility in Russian Firms', California Management Review, Vol. 45 , no.3, pp.59-77. 
37. Michailova, S., Hutchings, K. (2006), 'National Cultural Influences on Knowledge Sharing: A Comparison of China and Russia', Journal of Management Studies, vol. 43 no. 3, pp. 383-405.

38. Nonaka I. and H. Takeuchi H. (1995), The Knowledge-creating Company: How Japanese Companies Create the Dynamics of Innovation, New York, NY ; Oxford, UK: Oxford University Press, New York, NY ; Oxford, UK.

39. Osland, J.S., Bird, A. (2000), 'Beyond sophisticated stereotyping: Cultural sense-making in context', Academy of Management Executive, vol. 14 no. 1, pp.65-80.

40. Ralston, D. A., Holt, D. H., Terpstra, R. H. and Yu, K. C. (1997), 'The impact of national culture and economic ideology on managerial work values: a study of the United States, Russia, Japan and China', Journal of International Business Studies, 28, 1, 177-207.

41. Schein, E. (1992), Organizational Culture and Leadership, Jossey-Bass Publishers.

42. Schumpeter, J.A. (1934), The Theory of Economic Development, Harvard University Press, Cambridge, MA.

43. Shane, S. (1993), 'Cultural Influences on National Rates of Innovation', Journal of Business Venturing, Jan93, Vvol. 8 no.Issue 1, pp. 59-74.

44. Shekshnia, S. (1994), 'Managing People in Russia: Challenges for Foreign Investors’, European Management Journal, 12, pp.298-305.

45. Shekshnia, S. (2004), 'The Three Faces of Peter the Great - Leadership Lessons from the St. Petersburg's Founder', INSEAD working papers.

46. Takeuchi, H. (2001), 'Towards a universal concept of knowledge management' In: Managing Industrial Knowledge (Nonaka, I., Teece, D., eds.), Sage, London, pp. 315 - 329,

47. Veiga, J. F., Yanouzas, J. N. and Buchholtz, A. K. (1995), 'Emerging cultural values in Russia: what will tomorrow bring?', Business Horizons, JulyAugust, 20-7.

48. Von Krogh G., Ichijo K, Nonaka I. (2000), Enabling Knowledge Creation. Oxford University Press: New York.

49. Weir D., Hutchings K. (2005), 'Cultural Embeddedness and Contextual Constraints: Knowledge Sharing in Chinese and Arab Cultures', Knowledge \& Process Management, vol. 12, no.2, pp.: 89-98.

50. Zhu, Z. (2004), 'Knowledge management: towards a universal concept or cross-cultural contexts?', Knowledge Management Research \& Practice, vol. 2 no.2, pp. 67-79. 